\title{
Estimated levels of some Hormones and immunoglobulin G,M in women infected with Chlamydia trachomatis in Al-Najaf governorate, Iraq.
}

Assist. Prof. Maysoon k.A. Al-Hadrawi / Technical institute/ Kufa ma6861@yahoo.com kais k.A .AL.Hadrawei / Master Microbiolog / Kaisnoor2013@gmail.com Lecturer Jasim Mohemmed Hasan /Technical inst.Kufa/ALgsm@yahoo.com

\section{Received:-11/12/2014}

Accepted:-20/1/2015

\begin{abstract}
This study was designed to determine the effect of Chlamydia trachomatis infection in women by of city of Najaf on levels hormones (prolactin, LH, FSH) and immunoglobulin G,M which included the current study, 30 cases of infection with the bacterium chlamydia and 20 cases of women who are not infected visited unit infertility in AL- Sadr medical City, and ALZahra Hospital in Najaf Al-Ashraf, for the period from June, until August 2014.
\end{abstract}

The present study showed a significant increase in the level of Ig M, G, where the level of Ig M in women infected (285.345mg / dl, 71\%) compared to the control group (146.166mg /dl,29\%) and the level of antibodies G (2896.93mg / dl, $66 \%)$ compared with control group $(1184.56 \mathrm{mg} / \mathrm{dl}, 34 \%))$. As the study was significantly increased in the hormone level of FSH and LH as the FSH level (17.104mg / dl ) compared to control group( 8.34mg / dl ) . while the LH (15.625mg / dl, 8.34mg / dl), respectively. The hormone prolactin did not record any significant change between the infected and at the level of the control group. The present study recorded significant increase in each of the levels( IgG ,M FSH ,LH ) but did not register a significant change in the prolactin level

Key Word: Chlamydia trachomatis, ELISA, IgG, IgM. 


\section{Introduction}

major causes of pelvic inflammatory disease

(PID) and infertility in women [5].

C. trachomatis is a pathogenic bacteria.

It cannot survive outside of a eukaryotic

host. In fact, humans are the only known

natural host for $C$. trachomatis. The

bacterium is transmitted by sexual contact

with an infected individual.[6]

Usually, C. trachomatis is asymptomatic in its hosts, but can cause discharge from the penis, pain and burning during urination ,infection or inflammation in the ducts of testicles, and tenderness or pain in the testicles. [7]

The life cycle of Chlamydia trachomatis consists of two stages: elementary body and reticulate body. The elementary body is the dispersal form, which is analogous to a spore. The dispersal form is about 0.3 um in diameter and

\section{Chlamydia trachomatis is an}

obligate, aerobic, intracellular parasite of eukaryotic cells. It is a Gram-negative bacteria and has a coccoid or rod shape. It has a cytoplasmic membrane and outer membrane similar to Gram-negative bacteria (thus, it being classified as Gramnegative) but, it lacks a peptidoglycan cell wall. C. trachomatis require growing cells in order to remain viable since it cannot synthesize its own ATP. Without a host organism, C. trachomatis cannot survive on its own $[1,2,3]$.

C. trachomatis is the leading cause of sexually transmitted disease worldwide--in the United States, alone, over 4 million cases are diagnosed each year. It is also the leading cause of preventable blindness (caused by a chlamydia infection called trachoma) in the world [4]. C. trachomatis is also one of the 
generation. The cell body has an incubation period of 7-21 days in the host. It contains no cell wall and is detected as an inclusion in the cell. After division, the reticulate body transforms back to the elementary form and is released by the cell by exocytosis. One phagolysosome usually produces 100-1000 elementary bodies [8].

Chlamydia is transmitted through infected secretions only. It infects mainly mucosal membranes, such as the cervix, rectum, urethra, throat, and conjunctiva. It is primarily spread via sexual contact and manifests as the sexually transmitted disease. The bacterium is not easily spread among women, so the STD is mainly transmitted by heterosexual or male homosexual contact [10]. However, infected secretions from the genitals to the hands and eventually to the eyes can cause trachoma [11].

The aim of this study is measurement of effect infection by Chlamydia trachomatis induces its own endocytosis upon exposure to target cells. It is this form that prevents phagolysosomal fusion, which then allows for intracellular survival of the bacteria. Once inside the endosome, the elementary body germinates into the reticulate body as a result of the glycogen that is produced. The reticulate body divides through binary fission at approximately 2-3 hours per Chlamydia replicate intracellular in what is called an inclusion--a membrane bound structure. This inclusion is able to avoid lysosomal fusion and degradation. Thus, the metabolically inactive elementary body form of Chlamydia is able to become the reticulate body. The multiplying reticulate bodies then become elementary bodies again and burst out of the host cell to continue the infection cycle. Since Chlamydia are obligate intracellular parasites, they cannot be cultured outside of host cells, leading to many difficulties in research [9]. 


\section{Subjects and Method}

\section{Diagnosis of Chlamydia trachomatis}

Chlamydia trachomatis diagnosis by used

Rapid detection of IgG Antibodies to

\section{Chlamydia}

trachomatis in serum samples

\section{Specimens}

temperature. After that the samples were centrifuged at $3000 \mathrm{rpm}$ for 5 minutes

(Backman /counter, Germany) to separate the serum and collected in other sterile tubes, each sample of serum was divided into three parts; each of them was kept in deep freeze at $-20 C^{\circ}$ till used for the determination of immunoglobin G,M, and Prolactin, FSH, LH.

\section{Method}

company (LTA, Italy) in accordance with the instructions and the company processed by the principle of (12). on levels of ( IgG,M. FSH.LH. Prolactin) in infected body in Al-Najaf governorate to compare that with control groups.

Samples were collected in the period from June until August 2014, 30 samples were collected from patients and 20 healthy who attended the clinics infertility center, AL-Sadder Teaching Hospital and ALZahra Hospital in AL-Najaf governorate, blood samples were also drawn from the patients by vein-puncture into specimen tubes and remains for 30 minutes at room

\section{Measurement of immunoglobulin's` (}

IgG, IgM) in the serum

Single radial diffusion method in the gel was used normally processed from the 


\section{Estimation of FSH ,LH . Prolactin hormone}

the methods of working with the accompanying kit. Before proceeding with the assay, bring all reagents, serum references and controls to room temperature $\left(20-27^{\circ} \mathrm{C}\right)$

\section{Statistical analysis Statistics}

infection with Chlamydia trachomatis was significant increase $(\mathrm{P}<0.05) \quad(285.34$ $m \mathrm{~g} / \mathrm{dl}$ ) in compared to control group $(146.16 \mathrm{mg} / \mathrm{dl})$, as seen in figure (1).
Was measured both prolactin and FSH, LH by enzyme- Linked immunosorbent assay method (ELISA) and kit of measuring hormones mentioned and manufactured by the USA company (Biocheck ,Inc). Hormonal tests were conducted based on

The data are analyzed using by SPSS statistical program. A $p$-value $\leq 0.05$ was considered statistically significant (13).

Relation between IgM Level and

\section{Chlamydia trachomatis infection}

The results of the current research decumnted that the levels of Ig M in women 


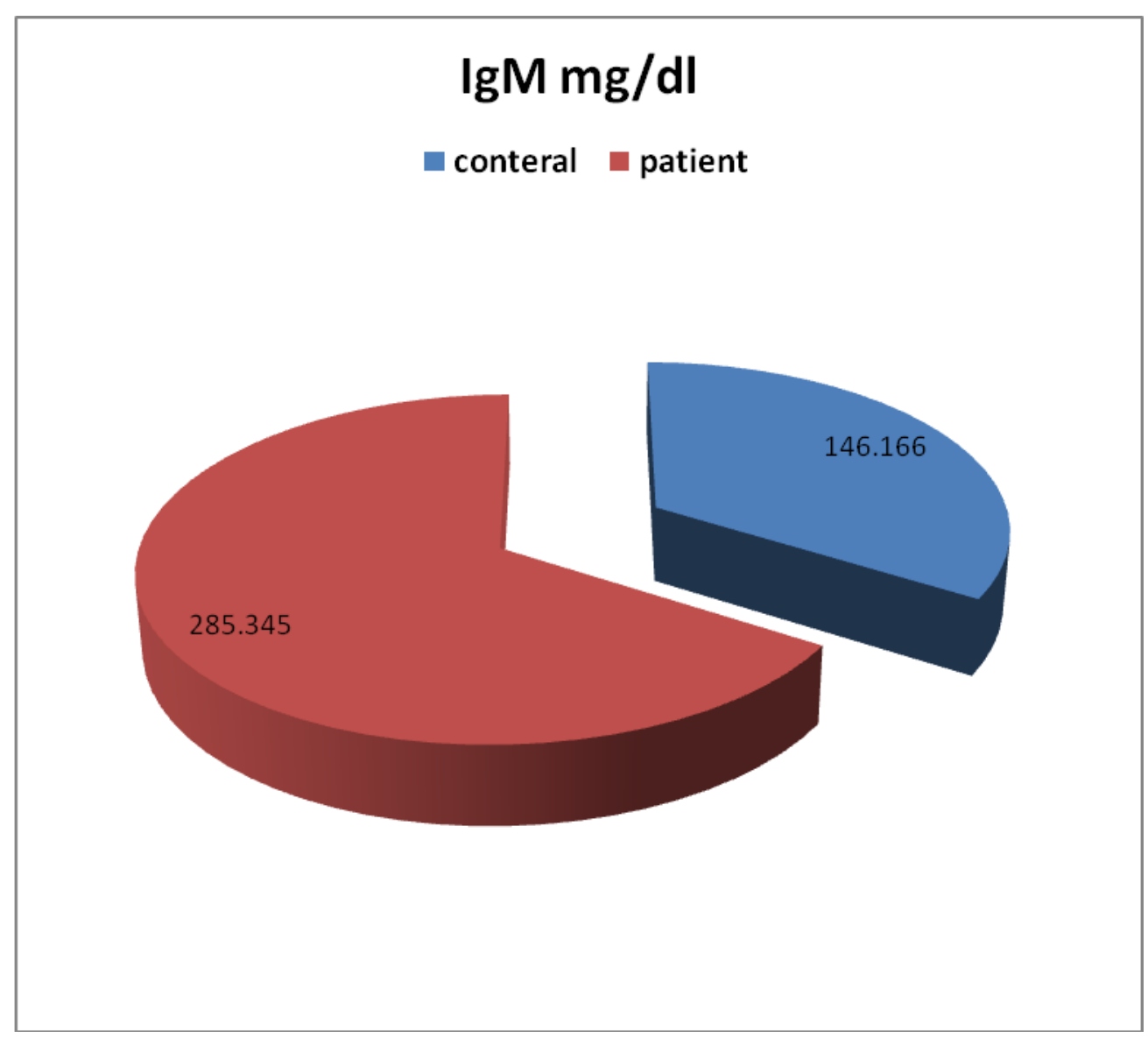

Figure(1) IgM levels of Chlamydia trachomatis patients and contral group.

*Significant difference between control group and patients $(\mathrm{P}<0.05)$

Relation between IgG Level and Chlamydia trachomatis infection

significant increase $(\mathrm{P}<0.05) \quad(1184.56$

$m \mathrm{~g} / \mathrm{dl})$ in compared to control group(

$2896.93 \mathrm{mg} / \mathrm{dl})$, as seen in figure (2).
The results of research discovered that the levels of Immunoglobulin $\mathrm{G}$ in women infection with Chlamydia trachomatis was 


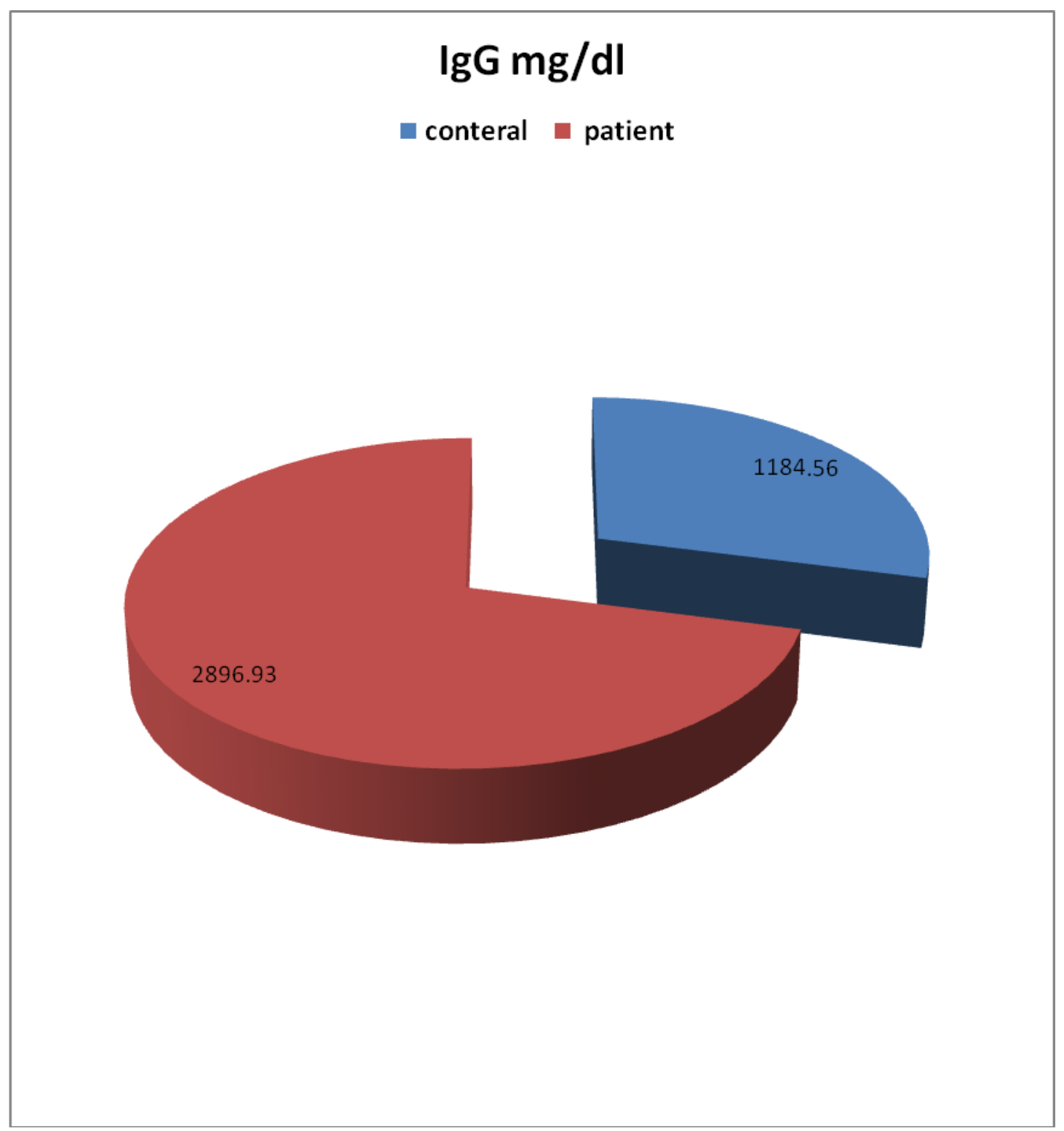

Figure(2) IgG levels of Chlamydia trachomatis patients and contral group.

* Significant difference between control group and patients $(\mathrm{P}<0.05)$

Relation between LH Level and Chlamydia trachomatis infection

significant increase $(\mathrm{P}<0.05)($

$15.625 \mathrm{IU} / \mathrm{L})$ in compared to control

group( $8.786 \mathrm{IU} / \mathrm{L})$, as seen infigure (3).
The results of research discovered

that the levels of $\mathrm{LH}$ in women infection with Chlamydia trachomatis was 


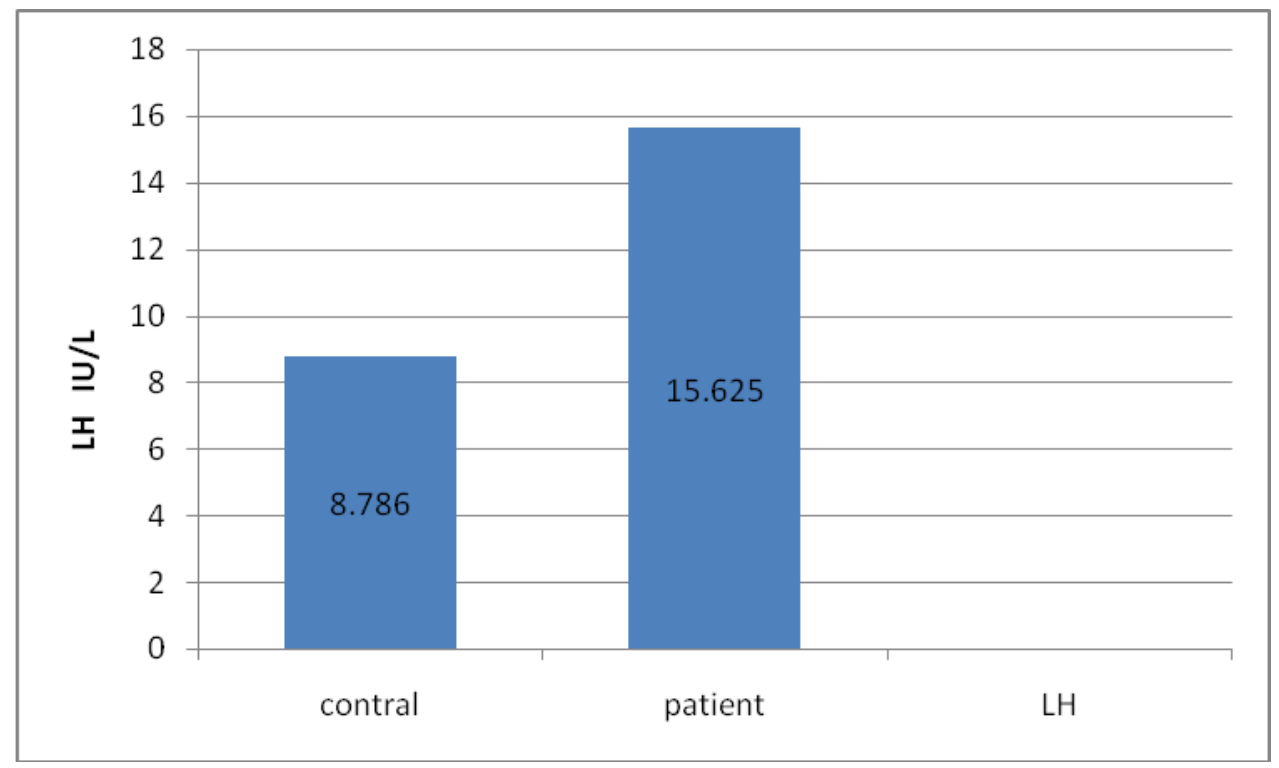

Figure(3 ) LH levels of Chlamydia trachomatis patients and control group.

*Significant difference between control group and patients $(\mathrm{P}<0.05)$.

\section{Relation between FSH Level and Chlamydia trachomatis infection}

increase $(\mathrm{P}<0.05)(17.104 \mathrm{IU} / \mathrm{L})$ in

compared to control group( $8.34 \mathrm{IU} / \mathrm{L})$, as

seen in figure (4).
The results of research discovered that the levels of FSH in women infection with

Chlamydia trachomatis was significant 


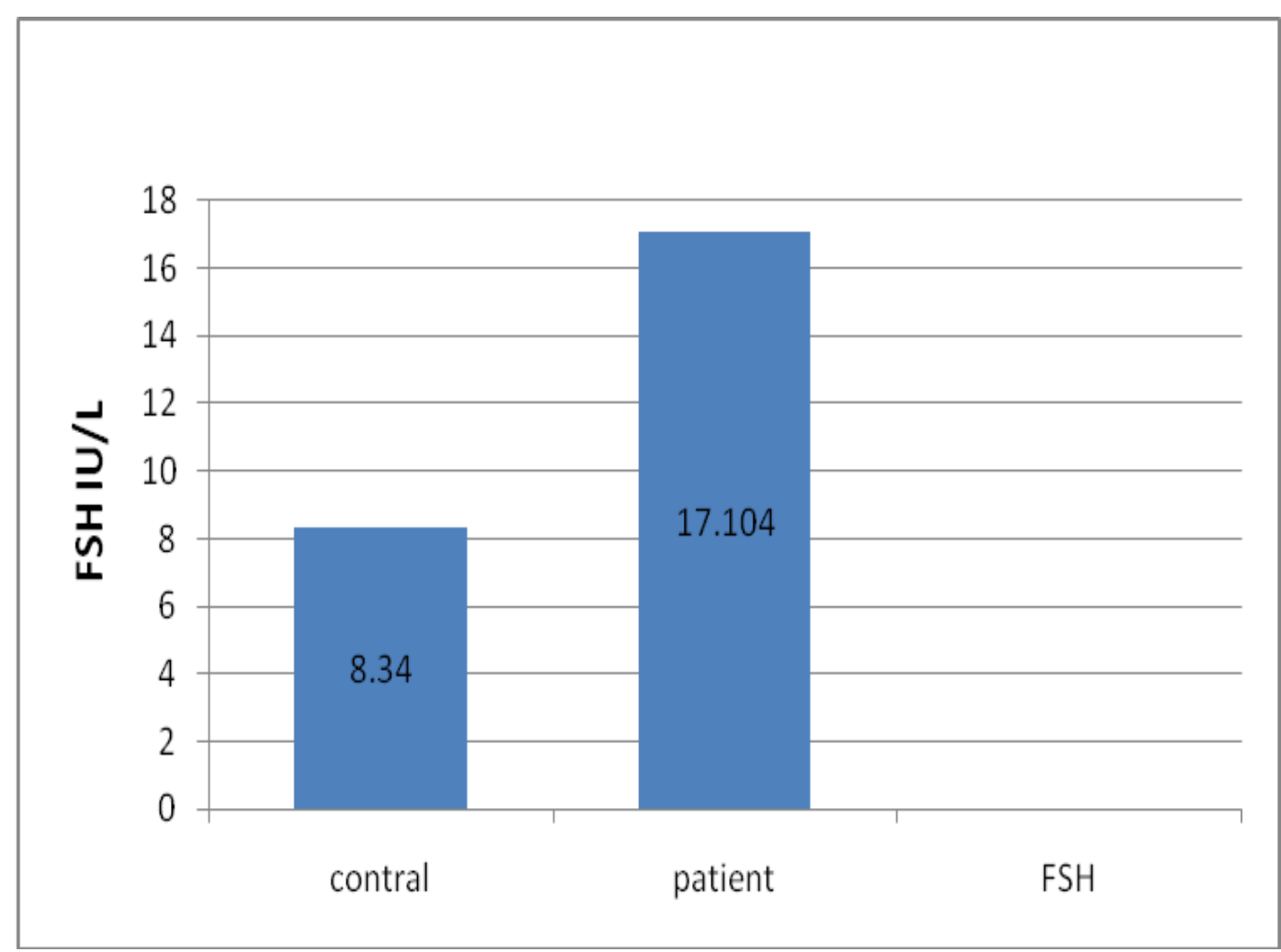

Figure(4)FSH levels of Chlamydia trachomatis patients and control group.

* Significant difference between control group and patients $(\mathrm{P}<0.05)$

Relation between Prolactin Level and Chlamydia trachomatis infection

change( $22.278 \mathrm{IU} / \mathrm{L})$ in compared to

control group(22.278 IU/L), as seen in

figure (5).
The results of research discovered that the levels of Prolactin in women infection with

Chlamydia trachomatis was non significant 


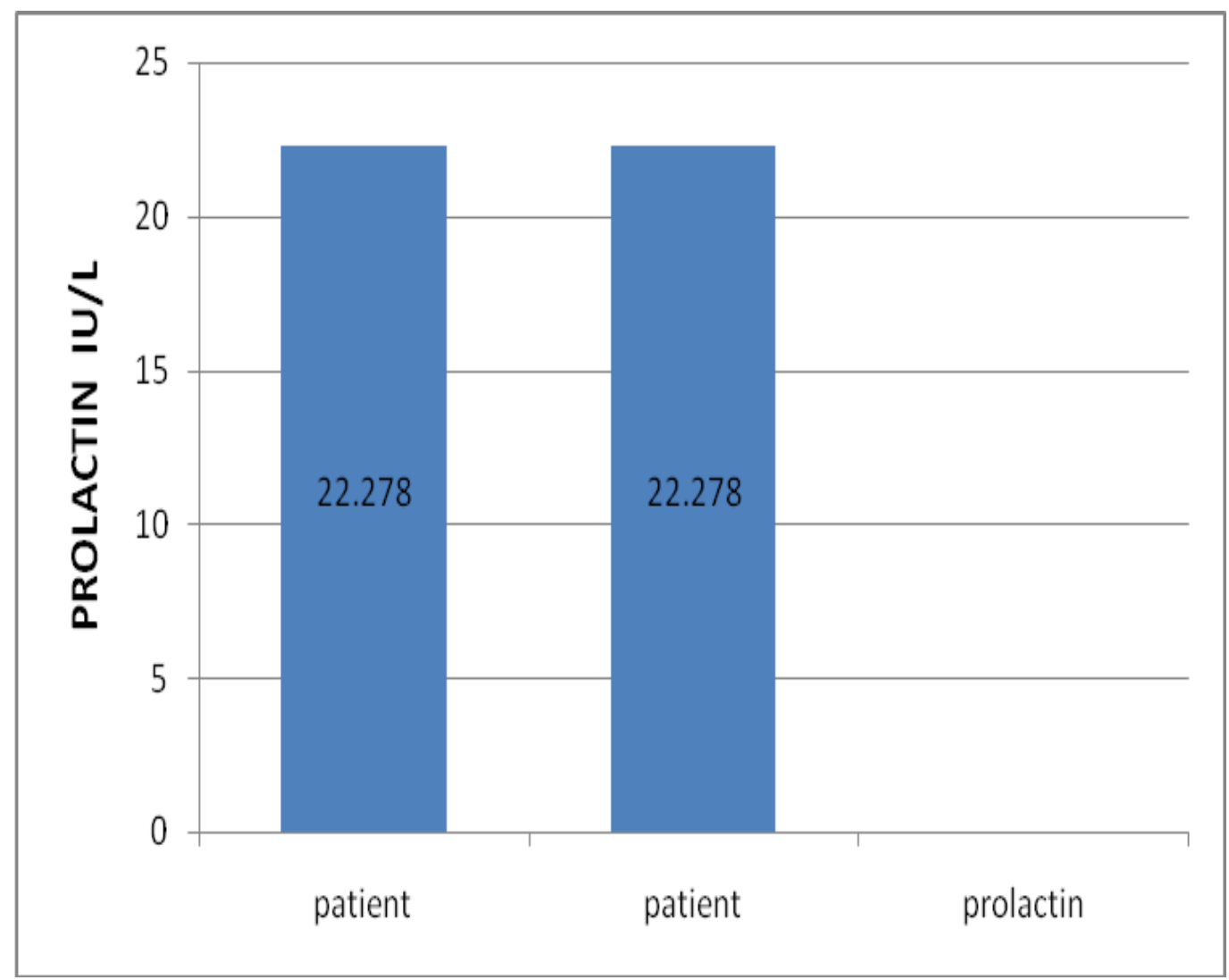

Figure(5) IgG levels of Chlamydia trachomatis patients and control group.

*Significant difference between control group and patients $(\mathrm{P}<0.05)$

\section{Discussion}

between infectious elementarybodies and a

replicating, reticulatebody.(14)

Serum anti chlamydial $\operatorname{IgM}$ was

the highest levels among infected women

(285.345 mg/dl) compared to (146.166

$\mathrm{mg} / \mathrm{dl}$ ) in controls groups (figure-1).also;

the anti chlamydial IgG level was raised in infected women( $2896.93 \mathrm{mg} / \mathrm{dl})$ while
Infection with $C$. trachomatis is

one of the major health problem,

particularly in developing countries. A wide range of antibodies has been reported to be produced following C. trachomatis infection because the organism has a unique biphasic life cycle, alternating 
past $C$. trachomatis infection because little is known how long specific antibodies may persist in individuals with resolved infections. This could indicate the most of the women with positive IgG antibodies might have become previously infected with C. trachomatis (19).

The female sex hormone LH and FSH are glycopeptides gondotrophin hormones. Its important in fertility.

Explained the current study the effect of infection with the bacterium Chlamydia trachomatis at the level of these hormones, which resulted in a significant rise in the level of FSH $(p<0.05)$ where the record level of FSH in women infected with $C$. trachomatis ( $17.104 \mathrm{I}$

increase may cause a negative feedback on the pituitary gland secretions and thus may cause irregular cycle and anovulatory bleeding with changing tissue including( controls group ( $1184.56 \mathrm{mg} / \mathrm{dl}$ ) ( figure -

2).it was found a significantly high level of $\operatorname{IgM}$ and $\operatorname{IgG}$ antibodies in women suffering from infection with C. trachomatis compared with control groups $(\mathrm{p}<0.05)$. Specific $\operatorname{IgM}$ antibodies have been associated with acute inflammation and recent infection of both IgM seropositive participants, while specific IgG antibodies reflect chronic inflammation and infection $(15,16)$.Polymerase chain reaction (PCR) testing revealed presence of C. trachomatis $\mathrm{IgG}$ in $8.6 \%$ of infertile women (17). While $32.4 \%$ were seropositive for the $\operatorname{IgG}$ to $C$. trachomatis in another study (18).However, it is difficult to estimate whether the presence of specific IgG antibodies reflects an acute, chronic or

U/L ) compared to the control group (8.34IU/L )fig.-3. As the level of LH shone high level compared to the control group $(15.625,8.786)$ IU/L respectivelyfig.-4. This 
genital Chlamydia trachomatis in women using PCR on urine specimen Lucknow, India; 21 (3): 301-304.

2- Stephens, Richard S. (2004) "Genome sequence of an obligate intracellular pathogen of humans: Chlamydia trachomatis." Science, 282: 754-759.

3- Brunham, Robert .( 2000). "Priming with Chlamydia trachomatis Major Outer Membrane Protein (MOMP) DNA followed by MOMP ISCOM Boosting Enhances

Protection and Is Associated with Increased Immunoglobulin A and Th1 Cellular Immune Responses." Infection and Immunity. 3074-3078.

4- Ryan KJ, Ray CG (editors) (2004). Sherris Medical Microbiology (4th ed.). McGraw Hill. pp. 463-70. ISBN 0-8385-8529-9

5- N. M. Budrys, S. Gong, A. K. Rodgers .(2012) “Chlamydia trachomatis antigens recognized in women with tubal factor infertility, normal fertility, and acute ovary, oviduct, uterine, and vaginal atrophy with a dehydrated and hyperpersensitive vaginal mucosa( 20) This contributes to the cause of infertility in the end. While the bacterium Chlamydia infection did not show any significant change in the level of the hormone prolactin injuries among women compared to the control group(22.278,

22.271) IU/L respectively. During our study of infertile women are advised to conduct a test Chlamydia trachomatis after year in order to treat and get rid of the problem.

\section{Conclusion}

It was concluded from the current study that Chlamydia trachomatis infection have a significant impact on the levels of Ig $\mathrm{M}, \mathrm{G}$, as well as its effect on the hormone FSH and LH while have no effect on the level of the hormone prolactin, as well as well as the study explained that chlamydia have a role in infertility in women

\section{Reference}

1- Vineeta , M.; Jyotsna, A. ; Amita, J.; Anoop, K .V. , (2010) : Prevalence of 
Chlamydia vaccines." Immunology (epub ahead of print).

\section{9- S. F. Coppus, J. A. Land, B. C. Opmeer} .(2011) “Chlamydia trachomatis IgG seropositivity isassociated with lower natural conception rates in ovulatory subfertile women without visible tubal pathology," Human Reproduction, vol. 26, No. 11, pp. 3061-3067.

10-Mancini, G.; Garbonara, A.O. and Hermans, J.F.(1965): Immunochemical quantitation of antigen by singleradial immunodiffusion. Immunochemistry

\section{2:235-254.}

11- C. M. Lardenoije and J. A. Land.(2007). "Chlamydia antibody testing for tubal factor subfertility,"

morbidity and the metabolic syndrome.

Chest 122:PP. 1587-1593.

13- Wong, B.Y.,Gnarpe, J., Teo, K.K.,Ohman, E.M., Prosser,C., Gibler,W.B., Langer, A.,Chang, W.C., Armstrong, P.W.Does chronic Chlamydia pneumoniae infection increase the risk of infection," Obstetrics and Gynecology, vol. 119, NO. 5, pp. 1009-1016.

6- F. van Aar, M. de Moraes, S. A. Morr'e .(2014) "Chlamydia trachomatis

IgGseroprevalence in the general population of the Netherlands in 1996 and in 2007: differential changes by gender and age," Sexually Transmitted Infections.

7-Wang, Y. (1999). "Etiology of trachoma: a great success in isolating ancultivating Chlamydia trachomatis." Chinese Medical Journal 112, 938 - 941. 8-Ananaba GA.( 2007). "Live-attenuated influenza viruses as delivery vectors for Nederlands Tijdschrift voor Geneeskunde, vol. 151, No. 36, pp. 1981-1985.

12- Falck, G., Gnarpe, J., Hansson, L.O., Svardsudd, K.,Gnarpe,

H.(2002).Comparison of individuals with and without specific IgA antibodies to Chlamydia pneumoniae: respiratory 
16. May K. Ismail and Amer S. Ali.(2012)"

Evaluation of Chlamydia Trachomatis

AntibodiesIn Women with Infertility"Al-

Mustansiriya J. Sci. Vol. 23, No 3,pp.: 21-

28.

17- R. C. Brunham, C. C. Kuo, L. Cles, and

K. K. Holmes.( 1983) "Correlation of host

immune response with quantitative recovery

of Chlamydia trachomatis from the human

endocervix," Infection and Immunity, vol.

39, no. 3, pp. 1491-1494.

18- Rashhidi, B.H., Tabriz L.C.,Haghollahi,

F.R., Zadeh F.R.,Shariat, M., Foroushani

A.R (2009).Prevalence of Chlamydia

trachomatis Infectionin Fertile and Infertile

Women; a molecular and serological

study.Reproduction and Infertility. 10(38).

20- Sorile, D. E. . (1995)." Medical

biostatics and epidemiology;Examination

and board review "first ed.

Norwalk,Connecticut, Appleton and Lange.

pp: 47-88. myocardial injury? Insights from patients

with non-

Televation acute coronary syndromes. Am

Heart J 144: 987-994. (2002).

14- Ibadin, K.O.,Onaiwn, I., Enabulele, O.I.

,Eghafona, N.O.,Aziken, M.E.Seroevidence

of Chlamydia trachomatis antibody in

infertile women in university of Benin

teaching hospital (Ubth) Benin city

Nigeria.Malaysian J of Microbiol.,6(1) :91-

93. .(2010).

15-S. A. Morr'e, A. J. C. van den Brule, L.

Rozendaal .(2002)“The natural course of

asymptomatic Chlamydia trachomatis

infections: $45 \%$ clearance and no

development of clinical PID after one-year

follow-up," International Journal of STD

and AIDS, vol. 13, supplement 2, pp. 12-18.

19-Wira,C.R.,J.V.Fahey,C.L.Ssentman

,P.A. Pioli,L., Shen. 2005.Innat and

Adaptive Immunity in female Genital Tract:

cellular Responses and Interaction.

Immunological Reviews 206:306-335. 
تقدير مستويات الاضداد المناعية M.G وهرمون المحفز للجريبات والهرمون اللوتيني وهرمون الحليب

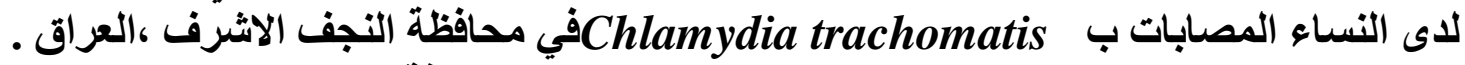
ميسون خضير عبد العباس المعهر التقي كوفة .

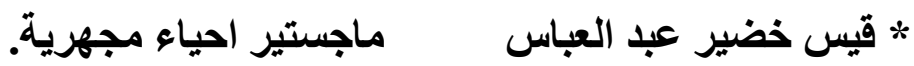
المعهد التقني كوفة.

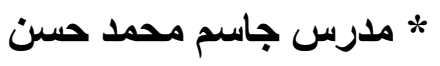

\section{كلية العلوم / جامعة القادسية}

* أسماء معن المحنها

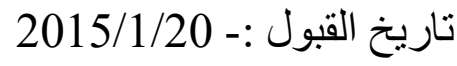
تاريخ الاستلام:- 2014/12/11

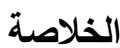

صُممت هذه الدر اسة لتحديد تأثثر إصابة النساء بال Chlamydia trachomatis في مدينة النجف على معايير بعض الهرمونات ( البرو لاكتين، الهرمون اللوتي FSH،LH ) ومستوى الأضداد M,G حيث اشتملت الدراسة الحالية على30 حالة إصابة ببكتيريا الكلاميديا و20 حالة من نساء غير مصابات ارتادوا مدينة الصدر الطبية ومستشفى الزهراء في محافظة النجف للمدة من شهر أيار حتى شهر آب2014.

أظهرت الدراسة الحالية ارتفاع معنوي في مستوى الأضداد M,G حيث كان مستوى الأضداد M لدى النساء

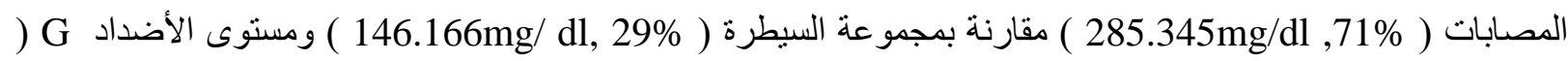
2896.93mg/dl,66\% ) لاى النساء المصابات مقارنة بمجموعة السيطرة (1184.56 mg/d1,34\% ) .كما سجلت

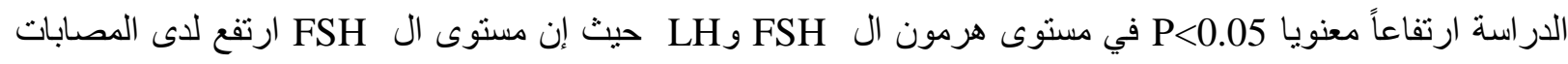
مقارنة بمجموعة السيطرة (15.625mg/dl ) LH 8.34mg/dl، 17.104 mg/dl ) على التوالي في حين ا ن ال 8.34mg/dl على التوالي. اما هرمون البرولاكتين فلم يسجل أي تغير معنوي بين مستواها لاى المصابات ومجموعة

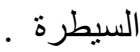

